Article

\title{
A View of the Disaster and Victory from below: Serbian Roma Soldiers, 1912-1918
}

\author{
Danilo Šarenac \\ Institute for Contemporary History, 11000 Belgrade, Serbia; E-Mail: sarenac.danilo@yahoo.com
}

Submitted: 22 January 2020 | Accepted: 29 April 2020 | Published: 4 June 2020

\begin{abstract}
The Kingdom of Serbia fought in three consecutive conflicts between 1912 and 1918. These events merged into a devastating experience of an all-out war, completely reshaping all aspects of contemporary life. As the first centenary of these events has recently shown, the memories of wartime still play a very prominent role in the Serbian national narrative. By 1915 around $20 \%$ of Serbian combatants belonged to some of the country's minorities. Second class citizens on the social margins of society, the Serbian Roma constitute those whose wartime history is the least known to research and the public. However, the wartime diaries kept by Serbian soldiers are full of causal references to their Roma fellow combatants. This article provides an overview of the duties Roma soldiers played in the war, based on the perspective of Serbs who were fighting alongside them. The article tackles the general image and the position of the Roma population in the Kingdom of Serbia. In addition, the horrific challenges the war created for Serbian society are tackled from the perspective of those who were, already in peace time, in the most disadvantageous situation socially and economically. Overall, despite the unifying experience which the wartime suffering imposed on all citizens of the Kingdom, the old prejudices towards the Roma survived after 1918.
\end{abstract}

\section{Keywords}

minorities; Roma soldiers; Serbia; warfare; World War I

\section{Issue}

This article is part of the issue "Gypsy Policy and Roma Activism: From the Interwar Period to Current Policies and Challenges" edited by Elena Marushiakova (University of St Andrews, UK) and Vesselin Popov (University of St Andrews, UK).

(C) 2020 by the author; licensee Cogitatio (Lisbon, Portugal). This article is licensed under a Creative Commons Attribution 4.0 International License (CC BY).

\section{Introduction}

In June 2017, pupils of Belgrade's Karadjordje primary school were celebrating the end of the school year. Traditionally, these celebrations included loud music, alcohol but also national symbols. A pupil belonging to the seventh grade was attacked by a group of others from the eighth grade. This was not another case of rising adolescent aggression which have befallen many Serbian schools. Rather, the argument of the attackers was that "one Roma cannot carry the Serbian flag" ("Roma pretukli jer je nosio srpsku zastavu," 2017). As the first centenary of World War I has just ended, it is convenient to address the issue of Serb-Roma relations precisely in terms of the 1914-1918 war. Formerly it is hard to overestimate the importance of World War I for Serbian national self-perception and collective memory. The war has been seen as an immense demographic and material disaster but also as a time of great heroism and ultimate victory. Consequently, were the Roma allowed to carry the Serbian flag then, during one of the most critical periods of Serbia's history, and how were they treated?

This topic does not only provide a chance to tackle inter-ethnic relations in the Kingdom of Serbia, or to shed more light on the Roma's past during this turbulent period. A number of phenomena within the scope of the culture studies of war can be examined as well. Following the conflict's dynamics, with a focus on the families of Roma soldiers, brings new insights into the level of devastation on the Serbian front. During the World War I the Roma were seen as fellow combatants, musicians or simply as bystanders (civilians). The available sources show that it is safe to say that the Roma shared all the experiences-good and bad-with Serbian soldiers and 
civilians. It is also clear that, despite their massive participation in the Serbian war efforts, the war failed to erase the existing pre-war prejudices and animosities. It also turned out that war memory was not used as an agent which could play a transformative role for the social position of the Serbian Roma.

The Serbian Centenary efforts, though massive and diverse, failed to address the issues linked to minority combatants. Dr. Dragoljub Ackovic organized a very successful exhibition focused on the suffering of the Roma during the Great War (Sretenović, 2019). Unfortunately, this was the only event in Serbia dedicated to this question. In contrast to other minorities within the Serbian army, the Roma soldiers can hardly be traced in bureaucratic records of the Serbian army. Consequently, other types of sources need to be looked for. For example, soldiers' diaries provide plenty of opportunities, as these bring casual remarks, comments and impressions about Roma individuals or their entire families. Indeed, diaries as a rule introduce an anecdotal form or information together with high level of subjectivity. It is important to stress that, so far, not a single Roma soldier's notebook has been found. Moreover, there is no surviving correspondence between soldiers and their families. As a result, at this point, it is impossible to say what the Roma soldiers thought about their experiences, struggles, fears or motivation. Therefore, this article draws extensively on diaries left behind by Serbian soldiers and, to a lesser degree, on newspaper sources. Materials left by Austro-Hungarian soldiers or other foreigners who visited Serbia were also consulted. This means that my text deals with the subject almost exclusively from the perspective of the Serbian majority. Such an approach certainly does not provide the conditions for broad-based conclusions. Observations made need further validation, preferably with statistical evidence. However, the article does offer sufficient instructive material for addressing some of the key themes of the Roma's wartime position. These include the military duties of the Roma men, but also the prevailing social attitudes towards this minority in the Kingdom of Serbia. The need to introduce the Serbian Roma into a broader interpretation of the Balkan front becomes even more apparent when we realize that almost nothing has been published on this topic. The work of Danijel Vojak remains a rare example of a study dealing with the Roma in the Balkans within the context of the Great War (Vojak, 2015).

\section{Soldiering as Socialization}

The Roma as Serbian combatants were mentioned in both of the Serbian uprisings organized in the 19th century (in 1804-1813 and in 1815). For example, the contemporary Vuk Stefanovic Karadžić wrote that "the Gypsies had their own commander during the uprising" (Acković, 2009, p. 91). In addition, the famous Serbian poet, Sima Milutinović Sarajlija, wrote about the heroism of the Roma combatants. The first Serbian uprising brought the Roma civil rights recognition, equality before the courts, freedom of religion, respect for customs and traditions as well as land heritage. However, these measures disappeared with the collapse of the Serbian insurgency. The Roma were offered similar rights after the second Serbian uprising, in 1815. However, it appears that this time the reforms did not bring palpable results. The historian Vladimir Stojančević explained this as the result of a weaker Roma presence in the rebel forces and its leadership than was the case in the previous uprising (Jakšić \& Bašić, 2005, pp. 20-21). The Roma reappeared as Serbian fighters during the turbulence of 1848. They were part of the forces sent from the Serbian Principality to Serbs living in Southern Hungary. Atanasije-Tasa Ivanović from the Serbian town of Jagodina, the man responsible for tax collection from the Serbian Roma, was ordered to form an exclusively Roma outfit:

With 850 skilful Gypsies, along with zurlas and drums, he continued during the freezing cold in December 1848. There were few of the Jagodina Gypsies, up to 300 , but others from Kragujevac, Pozarevac joined them along the way, following Tasa's order, which had to be executed unconditionally. Sabac, Smederevo and other places. There were up to 900 of them near Višnjica on the Danube. It was an unusual and very colourful army: One group (from Jagodina) wore the ordinary clothes, with pistols and holsters, curved sabres; others had more beautiful, colourful garbs with a scarf around their heads, with large belts, in which the guns were kept, together with the sharp knives, a whip with a lead top, and with rifles on their shoulders; on their feet they wore cavalry boots with spurs; their banners had various flags. (Cvetić, 1910, pp. 38-43)

Once across the Danube, fierce fighting ensued with the Hungarian army near the town of Arad. It has been recorded that 15 of the Serbian Roma soldiers were killed in this battle (Cvetić, 1910, pp. 38-43).

In 1883, a standing army with compulsory military service was introduced in the Kingdom of Serbia. This was one of many measures aimed at modernizing the state which had gained its independence in 1878. How did the Roma fit into this system, which was based on state bureaucracy and, above all, on the need for accurate addresses and years of birth? At first, the Serbian authorities were tolerant and aware that a number of Roma were clearly beyond the army's reach. For the time being only those Roma with permanent addresses and valid documents were called up. However, the state decided to recruit also the so-called 'wandering Roma.' In October 1891, the Serbian War Ministry made a decision that would significantly affect the way of life of the Roma in Serbia. It was a direct and dramatic interference of the state in the traditional way of life of native Roma: 
Many Gypsy vagrants avoid service in the unit and in the reserve. The reason is that as wanderers they cannot be processed through the census book in any municipality, so they are not recruited as such. In order to stop the waste of such material for the army, I order that all Gypsy vagrants, from 20 to 30 years of age, be recruited every year and sent exclusively to the infantry. Recruiting, reviewing and deploying personnel should be performed on the fifth day, after the other recruits have already been sent to the infantry. During the recruitment, there should be an interview of the Gypsy family in question, regarding the recruit's most frequent residence or place of work. When deployed, the district commanders will report to the battalion commander concerned, for each recruit, where each person will reside after serving. Upon dismissal, the battalion commander will report to the regiment in question about the trained soldiers, who will now be assigned to it as reservists.

As every year the infantry command issues a special call summoning its recruits, the commanders all regiment districts, as soon as they find out that such call has been published, will order to the administrative authorities in their area that on that day...all municipal authorities are obliged to bring to the headquarters all the Gypsy vagrants who are found in their district. Of these, all able-bodied persons who have not yet served in the military and who have not reached the age of 30 should be listed and trained.

The age of each Gypsy will be evaluated by the doctor attached to the district commander in chargeunless other documents are to be presented by the Gypsies themselves. ("Propisi, naredjenja i objašnjenja," 1891)

It is hard to estimate how efficient this measure was. It is reasonable to assume that it definitely increased the numbers within the Serbian army's contingent. It also brought about changes in the lives of many Roma. The long two-year stay in the army acted also as socialization process. Namely, one of the elementary activities in the army was the literacy course. On the other hand, the state was trying to transform all Roma into more permanent residents. It is important to note that the infantry was the only branch of the army reserved for the 'Roma wanderers.' This type of soldiering did not ask for any particular pre-existing skills unlike the artillery or engineering. And unlike the cavalry, no particular property (a horse) was needed.

In 1912 the state summoned its Roma reservists to arms. This was the First Balkan War. Among the hundreds of thousands of Serb soldiers ready to cross the Serb-Ottoman border, there were many Roma. One of them, a soldier named Ahmet Ademović, became part of Serbian military legends. Firstly, his performance at war shows that many Roma men acted in an exemplary man- ner in Serbian uniform. His biography also speaks a lot about patterns used when depicting Roma heroism, and more broadly, it offers insights into the wider trends in remembering the actions of Serbian troops during the 1912-1918 period. It is not clear who was the first to write down the story of Ahmet Ademović. In 1989 the military enthusiast Tomislav Vlahović published a book dedicated to the soldiers who had earned the highest Serbian military decoration: the Karadjordje Star. Naturally, he mentioned Ademović's story as well. By doing so he secured the preservation of the story for future decades. However, he wrote down two versions of the story which were circulating at the time.

The first version of these was that Ademovic had a crucial role in the Kumanovo battle of October 1912. This was the initial and most important clash of the Serbian and the Ottoman troops in the First Balkan War. The battle did not begin well for the Serbs who did not anticipate that they would run into the core of the Ottoman troops so soon after entering Ottoman territory. Vlahovic described how, at the most critical moment of the battle, Ademović gave a trumpet signal for the assault instead of the retreat-as he had been previously ordered by his commander. Ademović did so because he estimated, on his own initiative, that the moment was ripe for counterattack. Ultimately, his decision reversed the battlefield situation. In the second version, Ademović's action was even more audacious. It was claimed that Ademović was decorated because he actually disguised himself before the battle. Wearing Ottoman uniform, he went into the enemy camp where he deceived the enemy by playing a false signal-a trumpet sign for withdrawal (Vlahović, 1989 , pp. 85, 421).

Even with all the shortcomings of the Ottoman forces in 1912, something like this seems highly unlikely. Moreover, the idea that a battle involving tens of thousands of soldiers could be decided by a single private reveals a highly romanticised pattern of interpreting past. There is no doubt that Ademović earned his decoration in October 1912, but whatever he did, the post war storytellers transformed his exploits into a powerful myth. Within this myth we see certain roles reserved for the Serbian Roma. Moreover, these roles corresponded to their perceived peacetime characteristics. According to that pattern, the Roma were bold, skilful, cunning and good in deception. In the eyes of the Serbian storytellers it appeared as if the features attributed to the Roma, and which were criminalized in peacetime, suddenly became desirable at times of war as they provided a critical advantage to the Serbian army.

There were other Roma who secured high military decorations. One of them was Rustem Sejdić. Again, like Ademović, he was a unit's trumpeter. The popular story described his deed in similar tone to that of Ademović. Namely, his unit had participated in the famous battle for the Kajmakcalan heights in 1916, where on his own initiative, he gave a signal for the critical attack. He also played false trumpet signals in order to spread confusion 
within the Bulgarian units who were about to launch a fresh attack (Dimitrijević, 2015). Again, this is the stuff of legend. One man had shown initiative and had resolved the colossal carnage. As in the previous case, the Roma soldier was depicted as bold, artful but manipulative.

The last known Roma who won the Karadjordje Star was also, like Ademović, from the southern Serbian town of Leskovac. His name was Amet Ametović. In the popular version of events, he was an expert in throwing hand grenades (Ivanović, 2016). However, his case study shows how huge were the differences between facts and popular accounts that spread after the battle. What differentiated Ametovićs case from the two previously mentioned biographies was the fact that Ametović gave two interviews to the Yugoslav press, providing a sober account of his fighting days and his accomplishments. Firstly, he provided details lacking in the previous case studies - such as the name of his unit, and his commanders ranging from the regimental down to the unit level. He also explained his specific duties as well the actions which had earned him the decoration.

Explaining his exploit Ametović did not provide any breath-taking story. He was a corporal and was responsible for leading patrols on scouting missions. This happened in Western Serbia in the autumn of 1914, near the border town of Krupanj. Ametović's unit was involved in heavy fighting near one notorious position, the Captain's Fountain (Kapetanova cesma) close to the Drina River. He said the following:

We go at night and then we stumble upon the body of an enemy soldier. I stab him. The stiff human body does not move.... I whisper to my men: Don't be afraid, it's only a corpse. And that was our job during the days and during the nights.... fought for the King and for the Fatherland. We all fought heroically....However, the commander in June 1915 gathered our company together and read out: Amet Ametović is decorated with the Karadjordje Star; he then gave me this decoration. ("Jedini Ciganin nosilac Karadjordjeve zvezde zivi u Leskovcu," 1936; italics added)

He received his decoration during a pause on the Serbian front in summer 1915. His story, without any spectacular actions sounds realistic, underlying war's brutality. As he described it, it was a prosaic and merciless business while the very decoration was the result of continuous activity by the entire squad.

Roma civilians had often been mentioned in the memories of contemporaries but their presence in soldiers' diaries was almost exclusively linked with the darkest sides of the war. Survival for many Roma was extremely difficult even in peacetime, but in wartime it became very precarious. The most vulnerable category of the population saw the battleground as a place where its limited survival resources could be replenished.

Journalists following the operations of the Serbian army near Shkoder recorded the following scene where the Roma 'cleaned up' the battle ground. It took place in February 1913:

The Serbs had around one thousand dead after their attack on the Brdica positions. They all remained on the field bellow the hill and they were still not able to bury them. Gypsies are usually used for this work, they gladly do so in the hope of booty. Turkish soldiers have already deprived the dead of their weapons, but there are still some left and the Gypsies are back with shoes, belts, caps, handkerchiefs and underwear. In their camp, near the bazaar, they later share the loot. Tonight, four Gypsy women left their camp to wait for their husbands, and when they spotted them, they went to meet them. At that moment, a shrapnel, coming over from Shkoder, burst over their heads killing them all. (“Iz Skadarske epopeje," 1913)

\section{As Soldiers in World War I}

In 1914, the Roma were called up again. The Swiss criminologist who came to Serbia, Rudolph Archibald Reiss, described a scene he witnessed in the autumn of 1914 which faithfully exemplifies shared patriotism and tragedy. It also however illustrates the naivety with which some Roma approached modern warfare, expecting it to be an extremely brief encounter between two armies after which things would quickly go back to normal. This happened in the town of Valjevo:

The streets in front of the Sekulic Hotel, which is on the corner, are full of people and wagons. Everywhere, next to the walls, sit the middle-aged peasants who come to report to their units belonging to the third levy. Waiting to come before the control commission, they eat and take a sunbathe. Among them, there are also Gypsies with their bronze faces like Indians. They are surrounded by their family members, women and children, who carry supplies. One very old Gypsy woman, with a pipe in her mouth which is almost solely composed of the tobacco chamber, sits on the doorstep of a house. They tell me she accompanied her son three days ago, he left with his regiment, and she is waiting for him to return. Poor grandmother, you will probably wait in vain! This world is silent, serious, but in the bright eyes of this people I see that they are determined to defend their country's independence and are not afraid to sacrifice their lives for this. (Reiss, 1928/1991, p. 11)

There are numerous mentions of the Roma as part of military music too. The Gypsy band is mentioned as a standard feature in celebrating military victory. Here, by focusing on the Roma minority it is also possible to see various elements of combat culture. One officer, Mladen Zujović, wrote about the atmosphere after the Battle of Kolubara, when in 1914 Austro-Hungarian troops had been expelled from Serbia for the second time. Euphoria 
after victory, alcohol but also boredom, characterised the days of Serbian officers in between battles in 1914 .

"In the third battalion, which is just next to us, the Gypsies are playing and the loud singing can be heard" (Žujović, 2004, p. 66). The Roma musicians were there too for Zujović and other officers during leisure time: "We often drink with Gypsies, but also without them, as they have often been taken from us by the artillerymen and other senior commanding officers who all now arrange frequent parties" (Žujović, 2004, p. 83). Music was also of great importance for maintaining morale before combat. One Serbian officer, Vojislav Šikoparija, wrote about this in his memoirs, stressing the importance of music while approaching the front zone when soldiers needed to overcome their gut-wrenching feeling:

There were good singers in the company, and several Gypsies, with their inevitable Gypsy violins, and soon a powerful folk song was heard. Milorad remembered his old practice from the Balkan Wars, so he took out and gave Firga a banknote so that he could "grease his violin a bit." Firga grabbed the banknote hoggishly, opened his mouth from one end to the other, and replied: "Well, Mr. Lieutenant, I will sing and play all the way to Pazar, so Djurdjevdan helped me." Really, tired and crookbacked under the burden of a rifle and other gear, Firga was suddenly full of liveliness, he cheered up and started singing and playing as if he was at a wedding in his native Tamnava village. His fellow brothers approached him, and they played so loudly that the whole regiment could now hear them. It was very pleasant to listen to them and somehow we moved in a more energetic and carefree manner. (Šikoparija, 2014, pp. 194-195)

Shikoparija described another scene which mentioned the Roma. This picture was very familiar to all Serbian soldiers and it again underlined the poverty in which so many Serbian Roma lived. The phenomenon was very similar to the one already noted in the llustrated War Cronicle of 1913 and its article about the Shkoder front. Namely, after each departure of Shikoparija's unit, from one camp to another, it was customary that Roma civilians were the first ones to come to the abandoned site searching for something useful among the soldiers' rubbish (Šikoparija, 2014, p. 198).

The movement of mass armies in 1914 had exacerbated the sanitary situation. By autumn 1914 the conditions became disastrously unhygienic, and from then until mid-1915 Serbia was hit by a typhus epidemic. Many Serbs easily linked the spread of the disease with their prejudices about the Roma's 'filth and dirt.' For example, in June 1915, at a session of the Belgrade Municipal Committee, the Committee of Physicians - in charge of health care in Belgrade-suggested that "Gypsies should be displaced outside the Belgrade area" ("Protest socijalista," 1915, p. 2). However, socialist deputies protested, saying that such a proposal "sets Gypsies apart from other Belgrade citizens and deprives them of the rights guaranteed to all citizens by the Constitution" ("Protest socijalista," 1915, p. 2). It is unclear how serious this proposal was, and eventually this idea did not materialize.

Links between the Roma and the fear of typhus can also be found in the diary of Natalija Arandjelović. This educated women belonged to the upper class of Belgrade residents. While her husband was fighting at the Salonika front, she stayed in occupied Belgrade taking care of their five small children. Her diary reveals that her family on several occasions was on the verge of starvation.

On 15 February 1918, Natalija Arandjelović wrote about a snowy day, lack of letters and news in general. She also wrote the following:

This evening a little Gypsy lost his way and came into our alley and he started to beg for money, he was five years old. I wanted to let him in to spend the night but I was afraid that he might carry lice so I reported him to the guard who took him into the station. He wasn't more than 5 years old. (Arandjelović, 2018, p. 339)

During the pause in fighting in 1915 one interesting book was published in Serbia. This was a romanticized divisional history written by its commander. The book was a collection of anecdotes about the war so far. Special emphasis was placed on the fate of the recruits who had come from the so called 'new territories,' meaning the lands Serbia had acquired in the 1912-1913 Balkan Wars.

One anecdote, second to last in the book, was dedicated to a Roma soldier. Entitled Escaped the Trap, the story focuses on Gypsy corporal Petar Vujičić. The author introduces Vujičić in the following way: "He is not the Gypsy like all others of his kind. He stands out. This is best illustrated by his corporal stars" (Milenković, 1915, pp. 61-62) Eventually, one day Vujičić is sent to lead a patrol on reconnaissance. He and his men are ambushed. However, instead of surrendering, corporal Vujičić reverses his position by screaming: "Hurrah! Throw your grenades right away!” (Milenković, 1915, pp. 61-62). This confuses the enemy, and Vujičić even manages to capture four of the Habsburg soldiers (Milenković, 1915, pp. 61-62). As in the previously described cases of stories where Roma's heroism and loyalty were promoted, here too the Roma soldier was using his cunningness and duplicity in order to achieve success. In addition, the idea that this soldier "was not a Gypsy like all others of his kind" reveals the strong stereotypes and shows the level of surprise when Serbians witnessed exemplary soldiering by the Roma.

Another interesting episode occurred in 1915. Precisely because of the way many Roma lived in Serbiaoften constantly relocating-Austro-Hungarian military intelligence decided to try a very daring operation. A group of spies was sent to Serbia, disguised as Roma. For the sake of authenticity, they were bringing a bear with them. When the spies were discovered after a while 
in Čačak, they were found with drawings of several Serb military positions (Vukanović, 1983, p. 193). Again, this episode needs further support from the sources but, regardless of its authenticity, it helps us understand how the two opposing sides on the Serbian front saw the Roma's place in their conflict.

One telling example of daily Serbian-Roma relations in the army can be found in the memoirs of the famous Serbian engineer, Miladin Pećinar. This episode speaks of a distance kept towards the Roma, but also shows how the Roma experienced this war. Pećinar described ascene from October 1915. At the time, he was a newly promoted sergeant, commanding one platoon stationed on the Serbian-Bulgarian border. The two countries were just about to wage war and the Bulgarian attack was imminent. Pećinar's orders were very clear: under threat of the death penalty, Bulgarian soldiers should not be fired upon, even if they began crossing the state border. The idea was that Serbia must not in any way provoke its neighbour.

I had a dozen Gypsies in my platoon, one of whom was a corporal. His name was Vlajko. They were scattered across the unit. Before the fighting began, they asked me to gather them all into one unit, their own group, and to put Corporal Vlajko as their commander. At first I rejected this proposal as I feared they might shirk their duties. However, soon I granted permission for this, especially when they explained to me what was behind the request. Namely, they said: We are Gypsies, so no one is eager to eat with us. Secondly, in the case of need, we can quickly help one another. After this explanation, I formed a unit, twelve of them, led by Corporal Vlajko. Before the Bulgarian attack, my platoon was located close to the village of Rogljevo on the Timok River. The Gypsy squad held the most forward defensive position. They were dug on a cliff above the Timok. At dawn, the Bulgarians started crossing the Timok without opening fire. However, Corporal Vlajko opened fire, killing several of them, while the others managed to escape in haste. This event alarmed the regimental headquarters. I spent the night tied up by the guards next to the regimental flag. The next day, I was to be sent before a court-martial. The verdict was known in advance. It was my good fortune that the Bulgarians went on a general attack that night along the whole front. The war started, so the earlier order became meaningless, I was not destined to be executed....One can imagine what my first meeting with Corporal Vlajko was like after all this. All bloody, he answered through tears, that he only afterwards realized what he had done, adding: Well, Mr. Sergeant, how can I not shoot when they are crossing the state border?! And indeed he was right. He, as a normal man, a soldier, could not comprehend our stupid order. He became very devoted to me and managed to bring more than half of his Gypsies to Corfu. He later died on Mount
Čeganj on the Thessaloniki Front. (Pećinar, 2004, pp. 112-113)

Pećinar also remembered humour as a standard feature of the Roma who served under his command. This is how he described one scene during the frenzy of the battle in autumn 1915:

While running toward the other pile of hay, one of my soldiers, a Gypsy, was running in front of me. Hit by a bullet somewhere in the bottom, he fell. As he fell, he yelled: Oh King Peter, I curse your mother! I thought that the Gypsy had died and I continued on. After a few days, moving away from Sokobanja to Aleksinac, I saw this Gypsy on horseback. And when I asked him how he was, he said: Behold, I am alive. And what, I said, would that be with King Peter? He answered, laughing: But I didn't say anything. (Pećinar, 2004, p. 114.)

The American socialist and journalist John Reed visited Serbia in 1914. In Macedonia, he too recorded an encounter with the Roma:

And always and everywhere Gypsies - men with some kind of silk turbans, women with gold coins instead of earrings and pieces and scrap of badges as dresses, barefoot-stamping the roads and carrying their wagons with them, or lying around the shabby vardos of their camps. (Reed, 1975, p. 22)

Later, as he approached the front, he recorded an encounter with Serb soldiers, including Roma:

Each regiment has two or three Gypsies, who march with units, playing Serbian violin, jingles, or bagpipes, and playing the songs constantly composed by soldiers-love songs, songs dedicated to victories, epic songs. All over Serbia, they are folk musicians, traveling from one rural glory to another, playing for a play and a song....Yet, only Gypsies in Serbia have no right to vote. They have no homes, no villages, no land-only their own queues and shabby carriages with awnings. (Reed, 1975, p. 16)

This remark is interesting. From the strict legal perspective the Serbian 1888 constitution had provided an extremely low property census promoting, practically universal, voting rights (Popov et al., 1983, pp. 91-92). However, whether the Roma practised their rights was a completely different story and still needs further scrutiny. Moreover, Reed's comment might be related to that part of the Roma population who were still without proper permanent addresses and thus unable to participate in the elections despite almost universal suffrage.

Another foreigner also touched upon SerbianRoma relations among his numerous impressions from Serbia. This was famous journalist, at that time Austro- 
Hungarian soldier, Egon Erwin Kisch. On 16 November 1914, he described in his diary the following scene, occurring near the town of Lajkovac:

We couldn't go further because of the huge columns of returnees from the town of Ub. The villagers stopped by their wagons in order to let us through. In doing so, I noticed a peasant woman moving away from a Gypsy woman. The class difference has not disappeared yet. Even now, when a peasant woman tosses around like a homeless person, like a beggar, she keeps an eye on the distance between herself and the Gypsy. (Kisch, 1983, p. 186)

Evidence of the Serbs' distance to the Roma can also be found in a book written by the famous Serbian Great War veteran, Živojin Lazić. He described a scene which took place during the Serbian breakthrough in 1918 and the liberation of the country. Namely, his commander ordered Lazić to go and find suitable accommodation for his superior:

I came to the village of Mladenovac. All the people had escaped and brought the cattle with them, so that the Swabians could not seized them. I found at the entrance to the village a house with a nice clean room. I booked it for the commander. I didn't even know it was a Gypsy's house. I found empty stables for horses and mules. (Lazić, 2006)

The next day, Lazić had to endure the commander's grudge: "Can you imagine that lieutenant Lazić found me an apartment in a Gypsy house, and now the whole unit is laughing at me" (Lazić, 2006, p. 97).

Lazić's commander was irritated at being too close to Roma while Lazić himself was puzzled as to how Roma could have such a fine house. There are other examples of such an attitude. One Serbian internee, apparently a member of Serbia's elite, was placed in the AustroHungarian Heinrichsgrin camp. He complained to the Serbian Red Cross in October 1916:

I have been interned here for two months with a group of 400 people or more. They didn't show any consideration for my position. I was imprisoned with Gypsies, gangs and peasants and they were chasing us like cattle. (Pandurovic, 1923/2014, p. 84)

The occupation of Serbia in 1915-1918 was very specific from the perspective of the Roma. The enemy authorities, following their own prejudices, often used the Roma for the dirtiest jobs. The famous Serbian veteran, Stanislav Krakow, wrote about one Roma who acted as an executioner in the Niš Fortress. Krakow wrote that the hangman continued living in Niš during the interwar years (Krakov, 1927).

Similarly, in 1918, the British Admiral Ernest Troubridge wrote that news that about the extent of
Bulgarian crimes committed in Serbia was slowly being discovered. The admiral was in contact with the British journalist of the Daily Mail, George Ward Price, who investigated Bulgarian crimes in Serbia in detail. Thus, Ward interviewed one of the Roma who was ordered by the Bulgarian authorities to clean up the site where Serbs had been executed by firing squads (Troubridge, 1918).

\section{After the War}

In 1935, the Belgrade daily Politika conveyed the unusual story of a soldier named Memet Abdijević. After 21 years, the soldier had already been 'mourned and forgotten' in his native Žitni Potok near the southern Serbian town of Prokuplje. This Roma had joined the Serbian army in 1913 and "people who knew Memet sa[id] he was a very good and reliable soldier" ("Ratna odiseja jednog Ciganina," 1935). He was twice wounded in 1915. On the Salonika Front, near Voden, he came into conflict with a Greek Army patrol and killed five Greek soldiers. He was soon arrested and sentenced to prison in Greece. After a long time, in 1933, he managed to contact the Yugoslav consulate and was released after their intervention (“Ratna odiseja jednog Ciganina," 1935). The stories of soldiers suddenly appearing in their villages, years after the conflict's end, were not unusual. However, this story had elements of a proper adventure. Whether true or not, it illustrated well the manner in which a good proportion of Serbs imagined the Roma-as eternal wanderers embracing extremely unusual life paths.

There must have been many Roma veterans among Serbia's post-war residents. However, these men were not part of the official Yugoslav commemorations. Yet, somewhere in the margins of society, their commemorations and mourning still took place. This is how one of Serbia's strangest memorials was created. The memorial was built without any knowledge of local or central authorities; there were no plans nor permissions. The origin of the monument was in connection with the commemoration of a non-canonized Orthodox Roma saint, Aunt Bibija. She is a saint who is believed by many Roma in Serbia to have saved Roma children from thecholera or plague epidemics in the 19th century. Aunt Bibija was celebrated in Belgrade's district, Čubura, where Roma had a large community. The monument therefore also embodying local identity.

In 1920, the Serbian press noted that besides the pear tree, which was important for Bibija's cult, there was a monument with the inscription: "Gypsies-Heroes who fell in the war of 1912-1918." Consequently, the monument was built sometime between 1919 and 1920, and the names of 54 Roma were engraved on it. The group which built this monument was called the Serbian Gypsy Youth. The sources also mention a slightly different inscription: "Serbian Gypsy Youth to their Heroes Who Were Killed and Died in 1912-1918" (Bogdanović, 2018, pp. 263-266). 
Due to the rapid expansion of Belgrade, the Roma however had to re-locate their monument as well as the place where they celebrated their saint. Thus, in 1927, the Association of Belgrade Gypsies Worshippers of Bibija bought a plot of land in Gospodara Vučića Street 49. There, a small chapel was built and the war monument was placed next to it. The monument still exists though only a handful of people in Belgrade are aware of its existence; it is almost unknown to historians and art historians dealing with monuments from the wars of 1912-1918. Only recently, the historian Branko Bogdanović wrote in detail about the site, mostly relying on the interwar press (Bogdanović, 2018, pp. 263-266). In addition, it is not on the list of Serbia's protected monuments, but procedures for placing it under legal protection were launched in 2019.

\section{Conclusion}

The presence of the Roma in Serbia's Great War efforts stands astride a very important thematic intersection. It testifies to the status of one of Serbia's minority groups, but also to a community in the most unfavourable position in terms of its social and material readiness for the cataclysm unleashed in August 1914. The story of the 'Roma in uniform' brings one more level of complexity to understanding the Balkan front. The Serbian army of 1914-1918 has usually been understood as a single-nation army-in contrast to multinational imperial troops. However, despite the high level of ethic homogeneity it also had its own internal ethnic dynamics that still need to be studied. The available sources strongly suggest that the Serbian Roma not only carried the Serbian flag in times of war but that they often fought with exemplary valour. The loyalty to their units was confirmed despite the initial prejudices and suspicion of their Serbian superiors. Suspicion, contempt as well as fear were regularly associated with the Roma in the eyes of many among the Serb majority. The army was not much different. Still, after the three consecutive wars their commanders and fellow soldiers saw them as skilled fighters, good in deception, audacious, resilient and adaptable. In addition, they had a critical role in boosting morale while acting as unofficial military marching bands.

Indeed, a question remains about the exact role of pre-war stereotypes in the minds of those who noted down in their diaries some words about the Roma soldiers they met. The war diaries and recollections present specific types of war record which are often random and incomplete. Nevertheless, despite all their imperfections and unanswered questions, they still present a vital source for making the Serbian Roma visible in the history of the World War I. Regardless of the pattern of storytelling, the qualities of the Roma soldiers were palpable as were the high decorations given to several Roma combatants. Yet these virtues were rarely publicly acknowledged. During the interwar years, individual Roma were certainly honoured, but the entire community was left outside the official Serbian narrative of the war. While the Yugoslav context proved to be more favourable for the position of the Serbian Roma, the pre-war prejudices proved to be too strong despite the war's 'fraternizing' impact. In addition, the Roma community did not manage to better its position and find a way to publicize its wartime loyalty and suffering.

\section{Acknowledgments}

I would like to thank Professor Mark Cornwall for kindly accepting to proofread this article.

\section{Conflict of Interests}

The author declares no conflict of interests.

\section{References}

Acković, D. (2009). Romi u Beogradu: Istorija, kultura i tradicija Roma u Beogradu od naseljavanja do kraja 20. veka [Belgrade Roma: History, culture and tradition of the Belgrade Roma since their arrival until the end of the 20th century] (1st ed.). Belgrade: Rominterpress.

Arandjelović, N. (2018). Dnevnik 1915-1918 [Diary 1915-1918] (1st ed.). Belgrade: Istorijski arhiv grada Beograda.

Bogdanović, B. (2018). Veliki rat. Zapisano u kamenu [The Great War. Written in stone] (1st ed.). Belgrade: Medijski centar Odbrana.

Cvetić, J. E. (1910). Spomenici Jagodine [Jagodina monuments] (1st ed.). Jagodina: Jagodina Gutenberg Printinghouse.

Dimitrijević, N. (2015). Ko je bio Rustem Sejdić? [Who was Rustem Sejdić?]. Leskovačke vesti. Retrieved from https://web.archive.org/web/ 20160921110952/http://leskovackevesti.rs/ leskovac-101-ko-je-bio-rustem-sejdic

Ivanović, M. (2016). Ahmed Ademović, zaboravljeni heroj Kumanovske bitke živi samo u sećanjima potomaka [Ahmed Ademović, the forgotten hero of the Kumanovo Battle lives only in memories of his ancestors]. Jugmedia. Retrieved from https://jugmedia.rs/ ahmed-ademovic-zaboravljeni-heroj-kumanovskebitke-zivi-samo-u-secanjima-potomaka

Iz Skadarske epopeje [From the Shkoder epic]. (1913, May 22). Ilustrated War Cronicle.

Jakšić, B., \& Bašić, G. (2005). Umetnost preživljavanja. Gde i kako žive Romi [The art of survival. Where and how the Roma live] (1st ed.). Belgrade: Institut za filozofiju I društvenu teoriju.

Kisch, E. (1983). Zapiši to, Kiš! Ratni dnevnik [Write it down, Kisch! War diary] (1st ed.). Novi Sad: Matica Srpska.

Krakov, S. (1927, June 26). Jezovita sećanja na doba bugarske okupacije. Tajne niške tvrđave [Gruesome 
memories from the days of the Bulgarian occupation. The secret of the Nis Fortress]. Vreme.

Lazić, Ž. (2006). Ratni dnevnik [War diaries] (1st ed.). Belgrade: Hrišćanska misao.

Jedini Ciganin nosilac Karadjordjeve zvezde zivi $u$ Leskovcu [The only Gipsy holder of the Karadjordje Star lives in Leskovac]. (1936, October 17). Pravda.

Milenković, D. (1915). Kako se Šumadinci bore. XIX puk I poziva u ratu sa Austrijancima 1914 [How the Sumadija men have been fighting. The XIX regiment in the war with the Austrians in 1914] (1st ed.). Belgrade: Štamparija Save Radenkovića i brata.

Pandurovic, V. (2014). Srpska pisma iz Svetskog rata 1914-1918 [Serbian letters from the Great War 1914-1918] (2nd ed.). Novi Sad and Belgrade: Prometej and Radio Televizija Srbije. (Original work published 1923)

Pećinar, M. M. (2004). Od Srbije do Jugoslavije: hronika dogadjaja kako ih je doživeo i ocenio jedan savremenik [From Serbia to Yugoslavia: The chronicles of the events as they were lived through and understood by a contemporary] (1st ed.). Belgrade: Institut za vodoprivredu Jaroslav Černi.

Popov, Č., Djordjević, D., Rakočević, N., Mikić, D., Milutinović, K., Krestić, V., . . . Ekmečić M. (1983). Istorija srpskog naroda [The history of the Serbs] (1st ed.). Belgrade: Srpska književna zadruga.

Propisi, naredjenja i objašnjenja [Regulations, orders and explanations]. (1891). Official Military Gazette.

Protest socijalista [The protest of the Socialists]. (1915, June 24). Politika.

Ratna odiseja jednog Ciganina [The war odyssey of one Gypsy]. (1935, August 15). Politika.

Reed, J. (1975). Rat u Srbiji 1915 [The war in Serbia 1915] (1st ed.). Obod: Cetinje.
Reiss, R. A. (1991). Šta sam video i proživeo u velikim danima. Saopštenje jednog prijatelja iz teških dana [Things i have seen and lived through during the great days. Notes of a friend from the hard times] (2nd ed.). Belgrade: Dereta. (Original work published in 1928)

Roma pretukli jer je nosio srpsku zastavu [The Roma were beaten because he carried the Serbian flag]. (2017, June 14). Večernje Novosti. Retrieved from https://www.novosti.rs/vesti/beograd.74.html: 670419-Roma-pretukli-jer-je-nosio-srpsku-zastavu

Šikoparija, V. (2014). Sećanja srpskog oficira (1900-1918) [The memoirs of a Serbian officer (1900-1918)] (1st ed.). Belgrade: Zavod za udzbenike.

Sretenović, M. (2019). Stradanje Roma u Prvom svetskom ratu [The calvary of the Roma in World War I]. Politika. Retrieved from http://www.politika. rs/sr/clanak/397309/Stradanje-Roma-u-Prvomsvetskom-ratu

Troubridge, E. (1918). War diary. Department of Documents, the Fitch Papers (Notebook No. 7). Imperial War Museum, London, UK.

Vlahović, S. T. (1989). Vitezovi Karadjordjeve zvezide sa mačevima Najhrabriji medju hrabrima [The knights of the Karadjordje star with swords. The bravest of the brave] (1st ed.). Belgrade: Tomislav S. Vlahović.

Vojak, D. (2015). Romi u Prvome svjetskom ratu u Hrvatskoj 1914-1918 [The Roma in World War I in Croatia 1914-1918] (1st ed.). Zagreb: Romsko nacionalno vijeće.

Vukanović, T. (1983). Romi (Cigani) u Jugoslaviji [The Roma (Gypsies) in Yugoslavia] (1st ed.). Vranje: Nova Jugoslavija.

Žujović, M. (2004). Ratni dnevnik. Srbija u I svetskom ratu [The War diary. Serbia in World War I] (1st ed.). Vrnjačka Banja: Interklima grafika.

\section{About the Author}

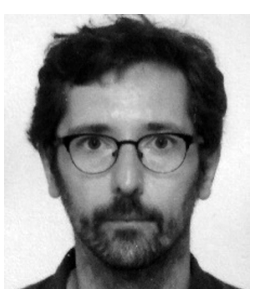

Danilo Šarenac is a Senior Researcher at the Institute for Contemporary History in Belgrade. His main research focus includes topics related to cultural and social aspects of the World War I in the Balkans. Phenomena such as social banditry as well as memories of the past conflicts have also occupied his attention. In 2014 he published the book Cannon, Soldier and Memory. Serbia and the World War I 1914-2009 (in Serbian). He also contributed to international volumes dedicated to the Great War. 